\title{
Evaluation of Whitefly Population and Weather Effect of Cassava Mosaic Incidence on Commonly Grown Cassava in Benue State, Nigeria
}

\section{1'TIME, I; ${ }^{1}$ OKOROAFOR, E; ${ }^{2}$ NWOGWUGWU, JO; ${ }^{3}$ BATCHO, AA}

\author{
${ }^{I}$ Department of Crop and Environmental Protection, University of Agriculture, Makurdi, Nigeria; \\ ${ }^{2}$ Department of Plant Pathology, Forestry Research Institute of Nigeria \\ ${ }^{3}$ Faculty of Agriculture \& Environmental Sciences, Catholic University of the West Africa Cotonou Benin \\ *Corresponding Author Email: anicetbatcho1@gmail.com
}

\begin{abstract}
Vector population and weather are critical in virus disease incidence and could be strategic for its management in agriculture. To investigate the influence of whitefly population and weather on Cassava Mosaic Disease (CMD) in cassava, TMS 419 and TME 30572, commonly grown in the state were planted. The varieties were laid out in Randomized Complete Block Design in four replicates and left to natural infection by CMD viruses. At two weeks after planting and fortnightly, whitefly population counts were taken, CMD incidence was estimated and severity scored on 5point scale. Daily temperature, humidity, wind speed and wind direction were obtained as secondary data. Data were analysed using ANOVA at $\mathrm{p}=0.05$. Whitefly population $(18 / \mathrm{plant})$ was significant ${ }_{(\mathrm{P} \leq 0.05)}$ in the first 30 days at $26.9-27.1^{\circ} \mathrm{C}$, $42 \%$ humidity, $10 \mathrm{Km} / \mathrm{hr}$ wind speed and when the wind direction was in the East or North-East. The vector population then declined until the end of experiment. Cassava mosaic incidence changed with whitefly population, humidity and wind speed. Disease incidence in cassava plots was low (3.6\%). TME30572 maintained lower disease incidence (3.0\%) and severity (2.0) during the study. $\mathrm{R}^{2}$ indicated that 27,42 and $57 \%$ of whitefly population could be explained by temperature, humidity and wind speed, respectively while $4 \%$ of the disease incidence could be explained by the whitefly population. The number of CMD infected plants peaked (4\%) when population of whitefly was $18 /$ plant, above which the disease reduced at 0.0017 rate per unit change in the vector population. Mosaic disease incidence in cassava plots was influenced by vector population as conditioned by the weather.
\end{abstract}

\section{DOI: https://dx.doi.org/10.4314/jasem.v24i10.20}

Copyright: Copyright $(02020$ Time et al. This is an open access article distributed under the Creative Commons Attribution License (CCL), which permits unrestricted use, distribution, and reproduction in any medium, provided the original work is properly cited.

Dates: Received: 15 September 2020; Revised: 09 October 2020; Accepted: 31 October 2020

Keywords: Bemisia tabaci, Cassava, Cassava Mosaic Disease, Nigeria, Weather, Whitefly vector

Cassava (Manihot esculenta Cranz) is a perennial shrub in the family Euphorbiaceae and a native to Latin America. Being a main staple in Africa, the crop is widely grown for food and feed for humans and livestock, respectively in many developing countries (Abaca et al., 2012). It is easy to grow and it thrives well in poor soils with little water and even under adverse climatic conditions. It offers several other industrial benefits such as starch and alcohol production (Nduele, 1993; Atthasampunna et al., 1987). Potentials of cassava yield have not been achieved in Africa, in spite of the large hectarage of land that is dedicated to its cultivation; this is due to several production constraints which has hampered maximum yield of this important crop (Legg, et al., 2015). Many diseases have been reported attacking the species, of which cassava mosaic disease (CMD) is ranked the most severe and widespread in sub Saharan Africa (Kaitisha 2003; Legg, et al., 2015). Yield losses resulting from mosaic diseases are responsible for some of the most severe crop losses of cassava in Africa. Whiteflies are the vectors associated with transmission of cassava mosaic in cassava fields.
Effective vector control has being a comprehensive strategy to disease management, particularly those of virus origin. In a standpoint of searching for effective strategy for fighting CMD, whitefly control could be targeted in a management of the disease (Thresh et al., 1997). Objectives of the study were to assess incidence and severity of the CMD on two cassava varieties, establish a relationship among incidence of the disease, whitefly population and some weather factors under field conditions in Makurdi.

\section{MATERIALS AND METHODS}

Source of Materials and Experimental Site: Stem cuttings of the two cassava varieties, TMS 30572 and TME 419, were obtained from the International Institute of Tropical Agriculture (IITA) by the Cassava Weed Management Project (CWMP).

The experiment was carried out in the University of Agriculture, Makurdi, as part of the CWMP. The site was situated between Latitude $07^{\circ} 47^{\prime} \mathrm{N}$ and Longitude $08^{0} 37^{\prime} \mathrm{E}$ at an elevation of $107 \mathrm{~m}$ above sea level. 
Field Layout and Experimental Design: A $380 \mathrm{~m}^{2}$ land was ploughed and harrowed after which $340 \mathrm{~m}^{2}$ portion was marked out for the experimental layout. The trial was laid out in a Randomized Complete Block Design (RCBD) and replicated four times. That is, the $340 \mathrm{~m}^{2}$ portion was demarcated into four blocks each measuring $17 \mathrm{~m}$ long $\times 4 \mathrm{~m}$ wide. Blocks were separated from each other by $1 \mathrm{~m}$ inter-space. A block was divided further into two plots with $4 \mathrm{~m} \times 6 \mathrm{~m}$ dimension per plot. One plot was given to each variety in each replication. Planting was done at the crest of raised ridges and $2 \mathrm{~cm}$ cuttings of each variety were planted per stand at about $7 \mathrm{~cm}$ depth. Twenty-five cuttings were planted per ridge and eight ridges made up a plot, the spacing was $1 \mathrm{~m} \times 1 \mathrm{~m}$ intra and inter-row giving a plant population of 200 plants per plot in eight rows of 25 plants per row. Missing stands, i.e. those that did not sprout were supplied one week after sprouting. Agronomic activities recommended for cassava management were carried out by the CWMP team.

Data collection and statistical analysis: Whitefly sampling: Cassava plants were sampled at random for whiteflies along the diagonal paths running through plots in ' $\mathrm{X}$ ' pattern following the procedure by Chikoti et al. (2015). A total of 20 plants were assessed per plot, 10 from each diagonal. Individual plot sampling involved scouting and counting the number of whiteflies on each plot selected per time. Each leaf was observed closely for whitefly at the abaxial part of the leaves sampled. Sampling of adults and nymph insect vectors was carried out in the morning and evening when the adult whiteflies were inactive.

Cassava Mosaic Disease Incidence and Severity Assessment: Mosaic disease assessment in cassava plots was carried out as described by Hahn et al. (1980) and Otim-Nape (1993). The incidence of cassava mosaic disease (D1) for a variety was estimated as a ratio of the number of plants showing mosaic symptoms and the total number of plants considered in a plot and expressed as a percentage.

$$
\mathrm{D} 1=\frac{C P M}{T P C} \times \frac{100}{1}
$$

Where $\mathrm{CPM}=$ number of cassava plants showing mosaic symptoms and TPC $=$ Total number of plants considered in a plot

Severity (DS) of cassava mosaic for each plot showing symptoms was measured on a 5-point scale. Severity scale which ranged from 1-5 had 1-symptomless or apparently healthy to 5-severe mosaic and distortion of four-fifth or more of the leaves. When computing the average severity, scores for the non symptomatic plants were left out and not considered (Sseruwagi et al., 2003). Data on whitefly count, disease incidence and severity were collected at two weeks intervals for sixteen weeks from November, 2015 to February, 2016. Daily weather readings such as temperature $\left({ }^{\circ} \mathrm{C}\right)$, relative humidity $(\%)$, wind speed $(\mathrm{Km} / \mathrm{hr})$ and wind direction during the period of experiment were obtained from the Nigeria Air Force Meteorological Station, Nigeria Air Force Base, Makurdi. Data collected were analyzed using ANOVA and means separated using FLSD $(\mathrm{p} \leq 0.05)$.

\section{RESULTS AND DISCUSSION}

Whitefly population: Whitefly mean population was low ( 8 per plant). The vector population peaked (18 per plant) in cassava plots only in the first 30days of the study (Table 1). This however, declined (9, 4, 3 and 2 per plant) continuously until no whiteflies were observed in the field. Except at 4WAP, TMS 30572 maintained a lower vector population all through the period of study.

Incidence and severity of CMD in cassava varieties under field conditions: None of the two varieties used in the investigation was immune to CMD infection. Significant difference $(\mathrm{P} \leq 0.05)$ in the incidence of CMD was recorded only at 4 WAP (Table 2). Disease incidence was generally low $(3.6 \%)$ in cassava plots. TMS 419 and TME 30572 had overall mean incidence of $4.2 \%$ and $3.0 \%$, respectively. Incidence of disease was higher $(4.0 \%)$ at $4 \mathrm{WAP}$ and $12 \mathrm{WAP}$ during the study. TME 30572 maintained lower (3.0\%) disease incidence all through the experiment. There was no significant difference $(\mathrm{P} \geq 0.05)$ in the severity of CMD in cassava plots. Symptoms severity was low (2.0) across cassava varieties. TME 30572 was lower (2.0) in severity all through except at 16 WAP.

Influence of temperature, humidity, and wind speed and wind direction on whitefly population build up in cassava plots: Although rainfall is a critical component of weather particularly with respect to disease studies, there was no rainfall during the period of study, hence no data was considered. Mean temperature in the cassava field was $27.1^{\circ} \mathrm{C}$ at the start of the experiment $\left(12^{\text {th }}\right.$ November, 2015) which dropped to $24.6^{\circ} \mathrm{C}$ in the next 34 days (Figure 1). This increased to $33.9^{\circ} \mathrm{C}$ in the following 76 days. Within this period, the whitefly count remained constant at 18 per plant in the first 18 days (12 to $30^{\text {th }}$ November, 2015) and then declined to 9 per plant in the next 31 days. The number per plant further decreased to two during the following 45 days and then to zero per plant at the last 15 days. 
Table 1. Whitefly Population Count on Two Cassava Varieties under Field Conditions in Makurdi

\begin{tabular}{llllllllll}
\hline & \multicolumn{1}{c}{ Weeks after planting } \\
\cline { 3 - 10 } Variety & Mean & 2 & 4 & 6 & 8 & 10 & 12 & 14 & 16 \\
\hline TME 419 & 8.1 & 20.2 & 16.2 & 8.9 & 10.0 & 4.3 & 2.7 & 2.2 & 0.0 \\
TMS 30572 & 7.6 & 16.0 & 19.9 & 8.9 & 7.7 & 2.9 & 3.0 & 2.2 & 0.0 \\
Mean & 7.8 & 18.1 & 18.1 & 8.9 & 8.9 & 3.6 & 2.9 & 2.2 & 0.0 \\
LSD (0.05) & $\mathbf{0 . 7}$ & $\mathbf{7 . 0}$ & $\mathbf{4 . 7}$ & $\mathbf{1 . 4}$ & $\mathbf{2 . 4}$ & $\mathbf{1 . 6}$ & $\mathbf{1 . 5}$ & $\mathbf{1 . 0}$ & $\mathbf{0 . 0}$ \\
\hline
\end{tabular}

Table 2. Incidence and symptom severity of mosaic disease in two CMD-resistant cassava varieties under field conditions in Makurdi

\begin{tabular}{|c|c|c|c|c|c|c|c|c|c|c|}
\hline \multirow[b]{2}{*}{ Parameter } & \multirow[b]{2}{*}{ Cassava Variety } & \multicolumn{9}{|c|}{ Weeks after planting } \\
\hline & & 2 & 4 & 6 & 8 & 10 & 12 & 14 & 16 & Mean \\
\hline \multirow[t]{4}{*}{$\begin{array}{l}\text { CMD } \\
\text { incidence }(\%)\end{array}$} & TMS 419 & 3.7 & 5.5 & 4.3 & 3.3 & 4.5 & 4.5 & 4.0 & 3.5 & 4.2 \\
\hline & TME 30572 & 3.1 & 2.4 & 3.4 & 2.9 & 3.3 & 3.5 & 3.2 & 2.7 & 3.0 \\
\hline & Mean & 3.4 & 4.0 & 3.9 & 3.1 & 3.9 & 4.0 & 3.6 & 3.1 & 3.6 \\
\hline & LSD (0.05) & 1.9 & 1.9 & 5.2 & 3.0 & 3.8 & 4.9 & 4.5 & 2.4 & 0.8 \\
\hline \multirow[t]{4}{*}{$\begin{array}{l}\text { CMD severity } \\
(1-5)\end{array}$} & TMS 419 & 2.2 & 2.0 & 2.1 & 1.9 & 1.9 & 2.1 & 2.3 & 2.0 & 2.1 \\
\hline & TME 30572 & 2.1 & 1.9 & 1.9 & 1.9 & 1.9 & 1.8 & 2.0 & 2.3 & 2.0 \\
\hline & Mean & 2.1 & 1.9 & 2.0 & 1.9 & 1.9 & 2.0 & 2.1 & 2.2 & 2.0 \\
\hline & LSD (0.05) & 0.2 & 0.4 & 0.5 & 0.7 & 0.7 & 1.3 & 0.7 & 0.7 & 0.2 \\
\hline
\end{tabular}

The quadratic polynomial for relationship between temperature and whitefly population in cassava plots was observed as $\mathrm{y}=-0.0377 x^{2}+0.9139 x+11.709\left(\mathrm{R}^{2}\right.$ $=0.2669$ ) (Figure 2). The equation showed that whitefly population peaked (18 per plant) at $26.9-$ $27.1^{\circ} \mathrm{C}$ and beyond or below this temperature the population declined continuously at 0.0377 rate per unit change in temperature. Percentage humidity in cassava plot during the experiment ranged from 14 to $59 \%$ (Figure 3 ).

The number of whitefly decreased continuously from 18 per plant to two in 63days. The equation $\mathrm{Y}=$ $0.0257 x^{2}+1.947 x-20.55\left(\mathrm{R}^{2}=0.4192\right)$ shows a polynomial relationship with wind, humidity and the build up of whitefly population in the cassava field (Figure 4). The relationship revealed a negative effect of humidity on the build up of whitefly population in the field. The population of whitefly peaked (18 per plant) at $42 \%$ humidity above which the population reduced at 0.0321 rate for every change in humidity. The speed of wind in cassava plots varied continually all through the period of study (Figure 5). Wind speed remained somewhat constant 9.9 to $10.0 \mathrm{~km} / \mathrm{hr}$ in the first 18days of the experiment (November 12 to $30^{\text {th }}$ November 2015), from where it rose sharply to $15.0 \mathrm{~km} / \mathrm{hr}$ at mid-December, 2015. The speed then declined to $13.5 \mathrm{~km} / \mathrm{hr}$ from the end of December and rose steadily for 30 days to $14.9 \mathrm{~km} / \mathrm{hr}$. Speed of wind picked up again from another decline to peak at $23.1 \mathrm{~km} / \mathrm{hr}$ in the last 15 days of the study. The quadratic polynomial, $\mathrm{Y}=0.1284 x^{2}-5.3441 x+$ $55.316\left(\mathrm{R}^{2}=0.577\right)$ defined the relationship between wind speed and whitefly population (Figure 6). The $\mathrm{R}^{2}$ value was high and indicated that about $57.7 \%$ of the whitefly population can be accounted for by wind speed.

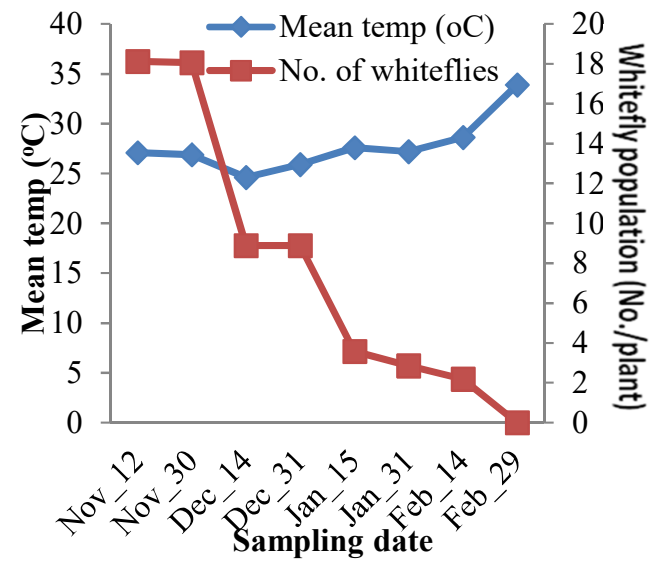

Fig 1. Whitefly population influenced by temperature from November 12, 2015 to February 29, 2016 in cassava plots.

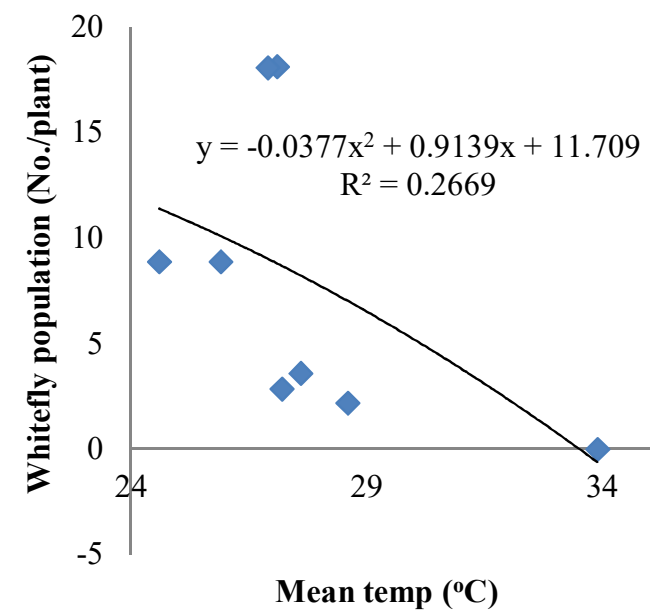

Fig 2. Relationship between mean temperature and whitefly population in cassava plots. 


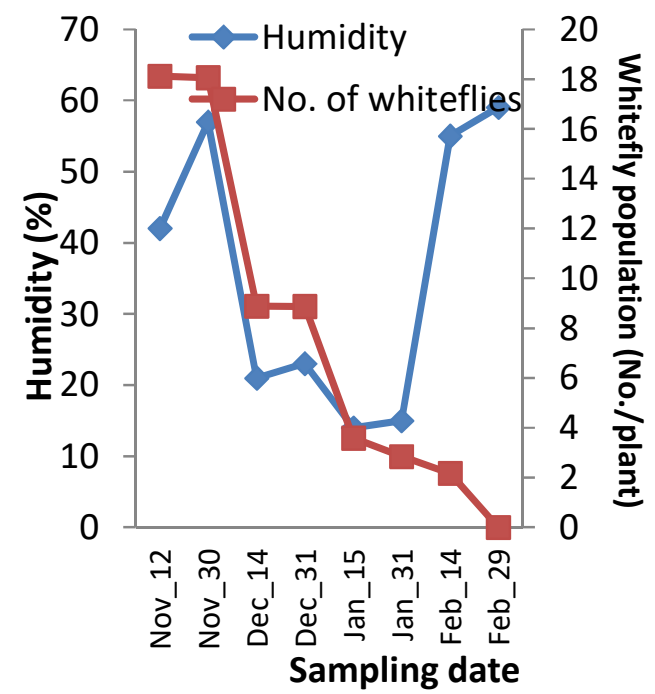

Figure 3 . Whitefly population influenced by relative humidity from November 12, 2015 to February 29, 2016 in cassava plots.

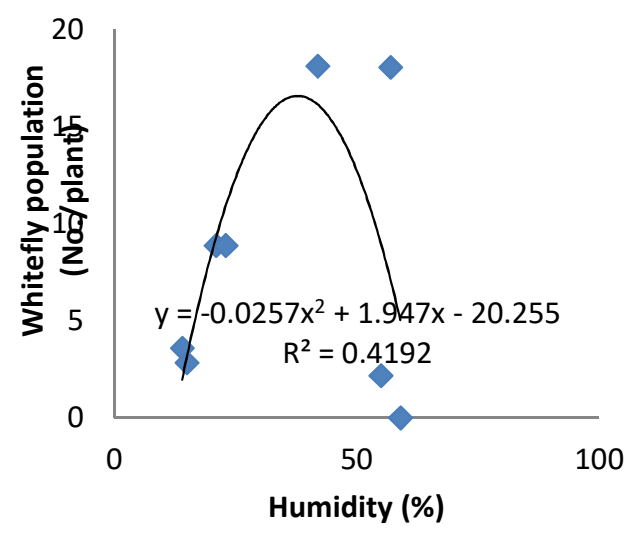

Fig 4. Relationship between relative humidity and whitefly population in cassava plots.

The equation also indicated that the number of whitefly per plant was highest (18 per plant) when wind speed was low $(10.0 \mathrm{~km} / \mathrm{hr})$ beyond which whitefly population decreased at 0.1284 rate per unit change in speed. Direction of wind across the cassava plots was more to the North followed by the East (Table 3). Whitefly counts were higher in the field when the direction of wind was either to the East (36 and $18 \mathrm{~km} / \mathrm{hr}$ ) or North-East particularly from the start of the experiment for 18days to the end of the study. Whitefly count fell drastically ( 7 - 0 per plant) when the wind change direction to the West, particularly to the North-North-West.

Build-up of whitefly population and its relationship with the incidence of CMD in cassava plots:

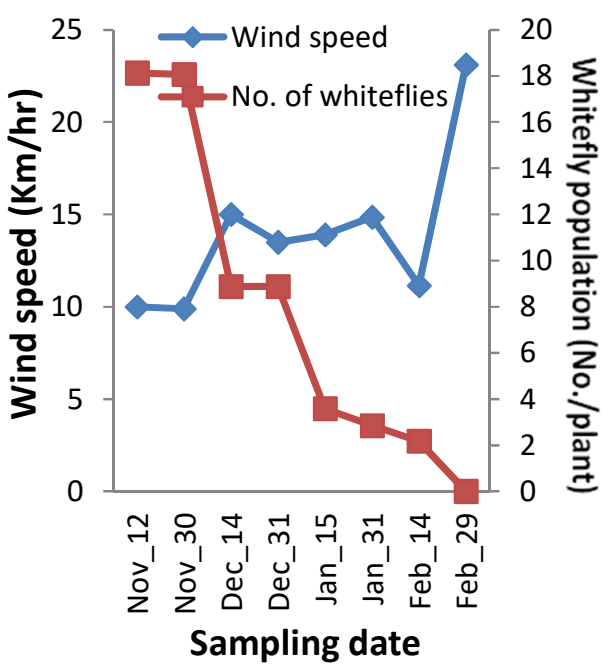

Fig 5. Whitefly population influenced by wind speed from November 12, 2015 to February 29, 2016 in cassava plots.

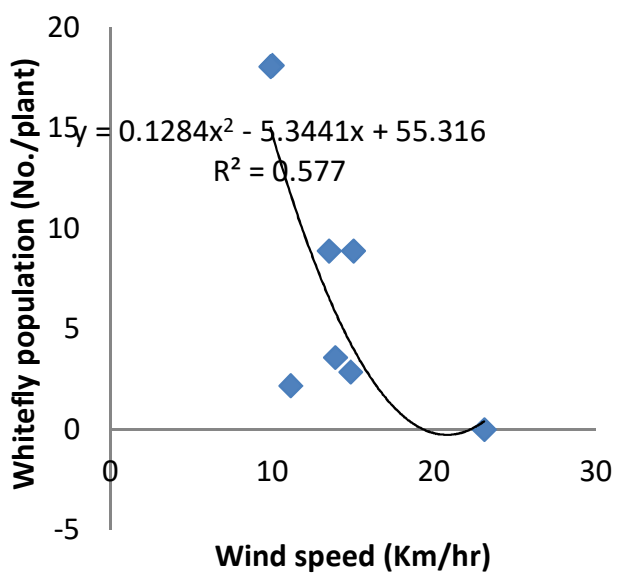

Fig 6. Relationship between wind speed and whitefly population in cassava plots.

Although, the number of infected plants was generally low $(<5 \%)$ and somewhat constant $(3-4 \%)$, it rose to highest (4\%) at 18 and 80days during the study (Figure 7). Number of infected plants finally dovetailed to $3.1 \%$ by the end of the study. Quadratic polynomials $\mathrm{Y}=0.0017 x^{2}+0.0403 x+3.4747\left(\mathrm{R}^{2}=0.0403\right)$ revealed the relationship between whitefly population build up and CMD incidence in cassava field (Figure 8). The relationship was positive, although neither significant $(\mathrm{P}>0.05)$ nor strong $(0.01)$. The $\mathrm{R}^{2}$ value which was low indicated that only $4 \%$ of the disease incidence could be explained by the population of whitefly. The equation suggests also that the number of plants infected with CMD was highest (3.6\%) when whitefly population was 10 per plant, beyond which the disease decreased at 0.0017 rate per unit change in whitefly population. 
Table 3. Whitefly population as influenced by wind direction in cassava plots in Makurdi.

\begin{tabular}{|c|c|c|c|c|c|}
\hline \multirow[b]{2}{*}{ Month } & \multirow[b]{2}{*}{ Date } & \multirow[b]{2}{*}{ Wind direction* } & \multicolumn{2}{|c|}{ Whitefly population (No./plant) on } & \multirow[t]{2}{*}{ Total } \\
\hline & & & TMS 419 & TME 30572 & \\
\hline \multirow[t]{2}{*}{ November } & $12^{\text {th }}$ & $\mathrm{E}$ & 20 & 16 & 36 \\
\hline & $30^{\text {th }}$ & $\mathrm{NE}$ & 16 & 20 & 36 \\
\hline \multirow[t]{2}{*}{ December } & $14^{\text {th }}$ & $\mathrm{NE}$ & 9 & 9 & 18 \\
\hline & $31^{\mathrm{st}}$ & NNW & 10 & 8 & 18 \\
\hline \multirow[t]{2}{*}{ January } & $15^{\text {th }}$ & SW & 4 & 3 & 7 \\
\hline & $31^{\text {st }}$ & SW & 3 & 3 & 6 \\
\hline \multirow[t]{2}{*}{ February } & $14^{\text {th }}$ & NNW & 2 & 2 & 4 \\
\hline & $29^{\text {th }}$ & $\mathrm{NE}$ & 0 & 0 & 0 \\
\hline
\end{tabular}

*E - East; N - North; S - South; W-West. Source: Meteorological Station, College of Agronomy, University of Agriculture, Makurdi

Low average population ( 8 per plant) of whitefly as observed in the cassava plots suggests resistance of the varieties to the vector involved. Moreso, lower vector population on TMS 30572 which was maintained all through the period of study when compared with TME 419 , reveals a greater resistance by the variety. Golding (1936) first noted that cassava varieties with greater resistance to CMD supported lower numbers of B. tabaci. Population of the whiteflies which peaked only in the first 30days (2 - 4WAP) of the cassava growth and its decline thereafter is a notable phenomenon, as observed by several other authorities. Rahman et al. (2006) observed a similar trend, although in tomato plots. Squire (1961) also reported increases in numbers of the vector associated with rapid cassava growth in their young stages. However, clearly apparent were the declines in the whitefly numbers during periods of slow cassava growth due to maturity. The phenomenon is therefore, attributed to preference of the succulent nature of the plants in their young stages by the insect vector. $B$. tabaci populations have consistently been reported to peak in the early stages of the crop, before declining more or less rapidly to a relatively low level for the remainder of the crop life (Fishpool et al., 1995). Continuous reduction in whitefly population might be due to maturity of the crop, which clearly does not favour the vector.

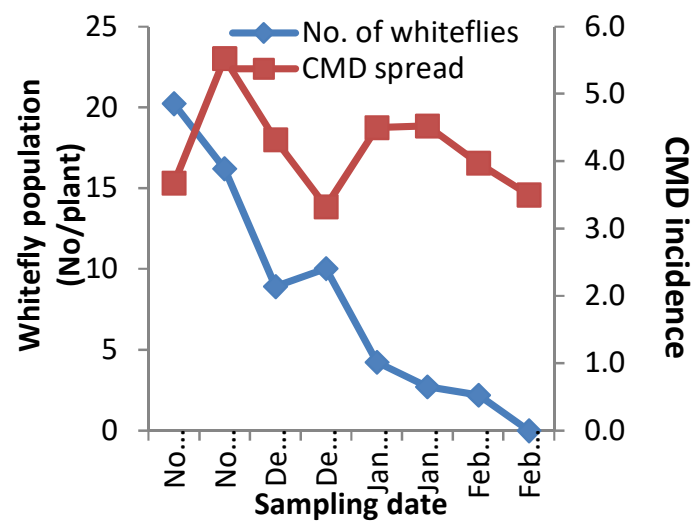

Fig 7. Incidence of CMD in cassava plots in relation to whitefly population between November 12, 2015 and February 29, 2016.

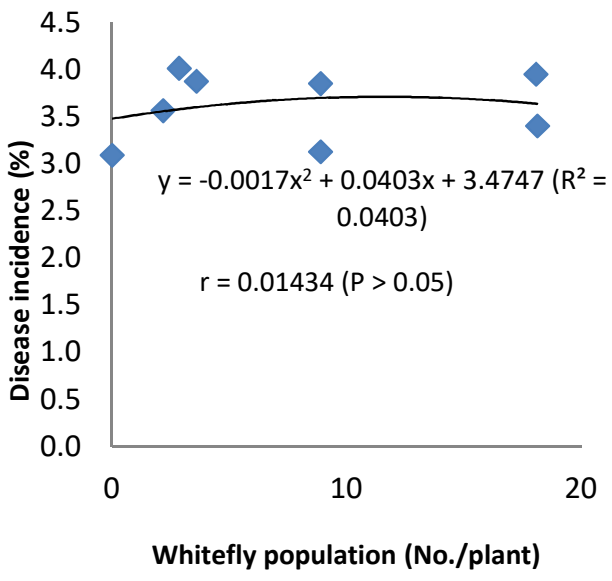

Fig 8. Relationship between population of whitefly and CMD incidence.

This observation corroborates Bock (1994) and Adebambo (1998) who recorded similar trends in two cassava varieties from July to September in their experiments. Rahman et al. (2006) observed that availability of preferred weedy plants outside the field could also reduce vector population. Squire (1961) provided the first suggestion that the physiological age of cassava plants was an important determinant of the pattern of $B$. tabaci population development, by demonstrating a decline in size of population as plants matured. Dengel (1981) and IITA (1990) recorded tuberisation in cassava roots as commencing $30-60$ days after planting, suggesting that the diversion of photosynthates associated with this change is likely to render aerial parts of the plant less suitable as feeding sites for B. tabaci. Observed low disease incidence and severity in cassava plots may also be as a result of resistance of these varieties to CMD infection. Again, similar observations were reported by Adebambo (1998) in the humid rainforest region of Nigeria. Severity of disease obtained in TMS 419 and TME 30572 were not significantly different throughout duration of the experiment. TMS 30572, however, recorded a lower disease incidence and symptom severity all through the experiment. This could suggest a superior resistance trait in TME 30572 to CMD over 
TMS 419. Steady increase in the mean temperature from mid-December to the end of the experiment was observed to correspond with a decline in the population of whitefly. This is in disagreement with Gupta (2000), who observed a positive correlation between temperature increase and whitefly population. Effect of temperature on whitefly population in this study is somewhat similar to other regions like Pakistan (Muhammad et al., 2017). Legg (1994) in Uganda, cited a publication by Legg and Fishpool (unpublished data), that numbers of B. tabaci and virus incidence were greatest in multi-location trials in locations with highest temperatures and that high whitefly populations occur during the main rainy season (April - June) following a period of hot dry weather in West Africa.

Root mean square $\left(\mathrm{R}^{2}\right)$ values indicated that about $42 \%$ of the whitefly population in the cassava plots can be explained by humidity. Also, in spite of considerable fluctuation in the percentage humidity, the quadratic equation revealed positive relationship with the whitefly population suggesting a favourable effect on the vector population. This observation, however contradicts other authorities (Rahman, 2006; Zeshan et al., 2015; Muhammad et al., 2017) whose results were contrary. This observation needs a further investigation with proper care for clarity and confirmation. Although, the root mean square $\left(\mathrm{R}^{2}\right)$ values which indicated about $58 \%$ of the whitefly population in the cassava plots as influenced by wind speed, Legg (1994) noted that the importance of wind has been emphasized in facilitating dispersion of the vector. That those distances $B$. tabaci adults can move successfully in wind currents are clearly essential in their ability to colonise new cassava fields and introduce CMD. The direction and speed of wind are known to influence distant and trivial movements of whitefly because of their abilities for sustained flights and into head winds (Isaacs et al., 2013). Wind is a critical factor influencing the incidence of viruses by air borne vectors. Prevailing winds also affect the direction of flight of the vectors.

The positive, low and weak value of the root mean square $\left(\mathrm{R}^{2}\right)$ in the polynomial equation between whitefly population and CMD incidence simply indicates that a relationship exists between the two. However, only a small proportion of the disease incidence can be explained by the whitefly population. The polynomial relationship also indicated that the rate of CMD infection in cassava plants was low (0.0017) for every change in whitefly population. Weather elements are among factors determining whitefly population dynamics and vector activity from season to season. Data from this study would be useful in formulating efficient management approaches against whitefly vectoring CMD viruses in cassava crop for increased productivity. Further work should consider exploring the effects of humidity on population of the whitefly vector and CMD incidence to clarify the contrast between results in this study and data from other authorities as noted.

Acknowledgement: We are grateful to the Cassava Weed management Programme, University of Agriculture, Makurdi (UAM) for permission to take data from their cassava experimental sites at UAM. Dr. H.I. Usman and Mr. O.Z. Angula, Station Scientist and Research Associate, respectively are appreciated for guidance and field assistance.

\section{REFERENCES}

Abaca, A; Kawuki, R; Tukamuhabwa, p; Baguma, Y; Pariyo, A; Alicai, T; Omongo, CA; Bua, A (2012). Evaluation of local and Elite cassava genotypes for resistance to cassava brown streak disease in Uganda. J. Agro 11 (3): 65 - 72.

Adebambo, AJ (1998). The relative disease incidence and severity of African mosaic virus in two cultivars of cassava during the rainy season over a period of three months from July to September, 1997. B. Agric. Project. University of Ibadan, Ibadan, Nigeria.

Atthasampunna, P; Somchai, B; Eur-arec, A; Antjarriyasripong, S (1987). Production of fuel ethanol from cassava. MIBCENJ. 3(2): 134 - 142.

Bock, KR (1994). Studies on cassava brown streak virus disease in Kenya. Trop. Sci. 34: 134-145.

Calvert, LA; Thresh, JM (2002). The viruses and virus diseases of cassava. In: Hillocks RJ; Thresh JM; Bellotti AC (eds) Cassava: Biology, Production and Utilization. Wallingford, UK: CAB International, Pp. 237-60.

Chikoti, PC; Tembo, M; Chisola, M; Ntawuruhunga, P; Ndunguru, J (2015). Status of cassava mosaic disease and whitefly population in Zambia. Afri. J. of Biotechn. 14(33): 2539-2546.

Dengel, HJ (1981). Untersuchengen uber das auftreten der imagines von Bemisia tabaci (Genn.) auf verschiedenen manioksorten. Zeitschrift fur pflanzenkrankheiten und pflanzenschutz 88: 355 366.

Dubern, J (1994). Transmission of African cassava mosaic geminivirus by the whitefly (Bemisia tabaci). Trop. Sci. 34: 82-91. 
El-Sharkawy, AM (2004). Cassava biology and physiology. Plt. Mol. Biol. 56: 481-501. Retrieved from https://www.researchgate.net/publication /8062875_Cassava_biology_and_physiology.

FAO (2016). Cassava production. FAO/GIEWS-Food Outlook. FAO, Rome, Italy. Retrieved from http://www.fao.org/faostat/en/\#data/QC.

Fishpool, LD; Farquet, C; Thouvenal, JC; Burban, C; Colvin J (1995). The Phonology of Bamesia tabaci Population (Homoptera; Aleyrodidae) on cassava in Southern Cot'dvoire. Bulletin of Entomol. res. 85: 197-207.

Fondong, VN; Sangare, A; Otim-Nape, GW; Farquet, CM (2000). Recombination pseudere combination and synergism of Gemini viruses are determinant keys to the epidemic of severe cassava mosaic in Uganda. J. Gen. Virol. 82: 65566.

Golding, FD (1936). Cassava mosaic in southern Nigeria. Bulletin of the Dept. of Agric. Nig. 11:1 10.

Gupta, ND (2000). Occurrence of Tomato yellow leaf curl virus and Tomato purple vein virus and their effect on growth and yield of tomato. Unpublished MSc. Thesis. Dept. of Plant Pathol. BSMRAU, Gazipur. p77.

Hahn, SK; Terry, ERT; Leuschner, K (1980). Breeding cassava for resistance to cassava mosaic disease. Euphytica 29: 673-683.

Harrison, BD; Zhou, X; Otima-Nape, GW; Liu, Y; Robinson, DJ (1997). Role of a novel type double infection in the geminvirus indicted epidemic of severe cassava mosaic in Uganda. Annals appl. Biol. 13: 437-448.

Hong, YG; Robinson, DJ; Harrison, BD (1993). Nucleotide sequence evidence for the occurrence of three distinct whitefly-transmitted geminiviruses in cassava. J. Gen. Virol. 74: 24372443.

IITA (International Institute of Tropical Agriculture) (1990). Cassava in Tropical Africa. A reference manual, IITA Ibadan, Nigeria 176pp.

Isaacs, DP; Martin, G; Harkins, P; Lemey, AJA; Gray, S; Meredith, F; Lakay, A (2013). The Spread of Tomato yellow leaf curl virus from the Middle East to the world. Plosogical Pathol. 6: 1-12.
Kaitisha, GC (2003). Some virus diseases of crop plants in Zambia. Pages 317-333 in: Proc. Plant Virol. sub-Saharan Africa. Hughes d'A J; Odu BO (eds). Int'l. Inst. Trop. Agric. Ibadan, Nigeria.

Legg, JP (1994). Bemisia tabaci: The whitefly vector of cassava mosaic Geminiviruses in Africa, an ecological perspective. Afric. Crp. Sci. J. 2(4): $437-448$.

Legg, JP; Lava Kumar, P; Makeshkumar, T; Tripathi, L; Ferguson, M; Kanju, E; Ntawuruhunga, P; Cuellar, W (2015). Cassava virus diseases: biology, epidemiology, and management. Adv. Virus Res. 91: 85-142.

Muhammad, J; Muhammad AK; Sohail, H (2017). Characterization of environmental conditions conducive for the development of Bemisia tabaci (Genn.) and tomato leaf curl virus disease. $J$. Entomol. \& Zoo. Studies 2017. 5(4): 1429-1432.

Muimba-Kankolongo A; Phuti K (1987). Relationship of cassava mosaic severity in planting materials to mosaic development, growth and yield of cassava in Zaire. Expt. Agric. 23: 221-225.

Nduele, M; Ludwig, A; Van Ooteghem, M (1993). The use of cassava starch in the formulation of gelatin capsules. J. Pharm. Belg. 48(5): 325 - 334.

Ntawuruhunga, P; Okao-Okuja G; Bembe, A; Obambi, M; Armand Mvila, JC; Legg, JP (2007). Incidence and severity of cassava mosaic disease in the Republic of Congo. Afric. Crp. Sci. J. 15 (1): 1 - 9.

Otim-Nape, GW (1993). Epidemiology of the African cassava mosaic Gemini virus disease (CMD) in Uganda. PhD Thesis, University of Reading, UK. Pp. 252.

Owor, B; Legg, JP; Okoa-Okuja, G; Obonyo, R; Ogega-Latigo, MW (2004). The effect of cassava mosaic Gemini virus on symptom, severity, growth and root yield of a cassava mosaic virus disease-susceptible cultivar in Uganda. Annals Appl. Biol. 143(3): 331-337.

Rahman, AHM; Akanda, AM; Ashraful Alam, AKM (2006). Relationship of Whitefly Population Build up with the Spread of TYLCV on Eight Tomato Varieties. J. Agric. \& Rural Dev. 4(1\&2): 67-74. 
Squire, FA (1961). Annual Report 1959 - 60. Department of Agricultural Research, Ibadan. Government Printers, Lagos, Nigeria.

Sseruwagi, P; Otim-Nape, GW; Osiru, DSO; Thresh, JM (2003). Influence of NPK fertiliser on populations of the whitefly vector and incidence of cassava mosaic virus disease. Afr. Crp. Sci. J. 11 (3): 171-179.

Storey, HH (1997). Virus diseases, on East African plants VI. A progress report on studies of diseases of cassava. East Afric. Agric. J. 2: 34-39.

Storey, HH; Nichols, RFW (1980). Studies of the mosaic diseases of cassava. Annals Appl. Biol. 25: 790-806.
Thresh, JM; Mbwana, MW (1997). Cassava mosaic and cassava brown streak virus diseases in Zanzibar. Roots 5 (1): 6-9.

Zeshan, MA; Khan, MA; Ali, S; Arshad, M (2015). Correlation of Conducive Environmental Conditions for the Development of Whitefly, Bemisia tabaci Population in Different Tomato Genotypes. Pak. J. Zoo. 47(6): 1511-1515.

Zhou, X; Liu, Y; Calvert, LL; Munoz, C; Otim-Nape, GW; Robinson, DJ; Harrison, BD (1997). Evidence that DNA-A of a geminivirus associated with severe cassava mosaic disease in Uganda has risen by interspecific recombination. J.Gen. Virol. 74: 2191-2111. 